\title{
Cardiovascular risk factors related to the PPAR $\gamma$ Pro12Ala polymorphism in patients with type 2 diabetes are gender dependent
}

\author{
Niclas Franck, Toste Länne, Olof Åstrand, Jan Engvall, Torbjön Lindström, \\ Carl Johan Östgren and Fredrik Nyström
}

\section{Linköping University Post Print}

\begin{abstract}
N.B.: When citing this work, cite the original article.
\end{abstract}
Original Publication:

Niclas Franck, Toste Länne, Olof Åstrand, Jan Engvall, Torbjön Lindström, Carl Johan Östgren and Fredrik Nyström, Cardiovascular risk factors related to the PPAR $\gamma$ Pro12Ala polymorphism in patients with type 2 diabetes are gender dependent, 2012, Blood Pressure, (21), 2, 122-127.

http://dx.doi.org/10.3109/08037051.2011.623349

Copyright: Informa Healthcare

http://informahealthcare.com/

Postprint available at: Linköping University Electronic Press http://urn.kb.se/resolve?urn=urn:nbn:se:liu:diva-76235 


\section{Cardiovascular risk factors related to the PPARY Pro12Ala polymorphism in patients with type 2 diabetes are gender-dependent}

Running title: NIDDM, PPAR $\gamma$ Pro12Ala and gender

Niclas Franck $\mathrm{PhD}^{1}$, Toste Länne MD Prof ${ }^{1}$, Olov Åstrand $\mathrm{MSc}^{1}$, Jan Engvall MD PhD ${ }^{1}$, Torbjörn Lindström MD PhD ${ }^{1}$, Carl Johan Östgren $\mathrm{MD} \mathrm{PhD}^{2}$ and Fredrik H Nystrom MD Prof $^{1}$, for the CARDIPP study group.

${ }^{1}$ Department of Medical and Health Sciences, Division of Cardiovascular Medicine, Linköping University, Linköping, Sweden, ${ }^{2}$ Department of Medical and Health Sciences, Division of Health and Society, Linköping University, Linköping, Sweden.

Address correspondence to:

Fredrik H. Nystrom MD, Ph.D, Professor

Department of Medical and Health Sciences

Linköping University

SE 58185 Linköping, Sweden.

Telephone; +46101037749

Fax; +4613145949

E-mail; Fredrik.Nystrom@lio.se 


\begin{abstract}
The interaction of the PPAR $\gamma$ Pro12Ala polymorphism with diabetes and cardiovascular risk is controversial. We studied 173 women and 309 men in the observational CARDIPP trial in which determination of left ventricular mass, carotid intima-media thickness (IMT), and pulse-wave velocity (PWV) were performed. Blood pressures were measured with 24-hour ambulatory technique (ABP). Heterozygotes and homozygotes of Ala were defined as Ala in the analyses. Men with Ala-isoform displayed higher waist circumference (Ala: $107 \pm 14 \mathrm{~cm}$, Pro: $104 \pm 11 \mathrm{~cm}, \mathrm{p}=0.045$ ) and body weight (Ala: $95.7 \pm 18 \mathrm{~kg}$, Pro: $91.6 \pm 14 \mathrm{~kg}, \mathrm{p}=0.042$ ) than Pro-homozygotes. Men with ALA-isoform also showed higher systolic ABP levels (Ala: 134 \pm 15 mmHg, Pro: $130 \pm 14$ mmHg, p=0.004) while left-ventricular mass-index, IMT and PWV were unrelated to isoforms. In contrast, carotid-radial PWV was lower in women with the Ala-isoform (Ala: $7.9 \pm 1.0 \mathrm{~m} / \mathrm{s}$, Pro: $8.5 \pm 1.3 \mathrm{~m} / \mathrm{s}, \mathrm{p}=0.01$ ) and levels of apolipoprotein A1 were higher (Ala: $1.43 \pm 0.27 \mathrm{~g} / \mathrm{l}$, Pro: $1.35 \pm 0.17 \mathrm{~g} / \mathrm{l}, \mathrm{p}=0.03$ ). In conclusion we found that men with type 2 diabetes having the Ala-isoform of PPAR $\gamma$ Pro12Ala had an unfavorable cardiovascular risk profile while women with this isoform had lower carotid-radial PWV and higher apolipoprotein A1 levels suggesting a beneficial prognosis. These differences according to gender of the ALA isoform in type 2 diabetes deserve further attention.
\end{abstract}

Key words: Cardiovascular disease, gender, hypertension, Peroxisome Proliferator Activated Receptor Gamma, polymorphism. 


\section{Introduction}

Obesity has reached epidemic proportions worldwide, and dysregulation of the adipose tissue metabolism may predispose to the development of insulin resistance, type 2 diabetes and hypertension. Over the past decade, substantial evidence indicate that genetic factors account for a great portion of the variation in human adiposity (1). The Peroxisome Proliferator Activated Receptors (PPAR) form a subfamily of the nuclear receptor superfamily of liganddependent transcription factors. The PPAR $\gamma$ subtype has been shown to regulate several genes of importance for adipocyte differentiation, lipid metabolism and insulin sensitivity (2). The $\operatorname{PPAR} \gamma$ receptor is present in two major isoforms, PPAR $\gamma 1$ and PPAR $\gamma 2$. The PPAR $\gamma 1$ is widely expressed whereas the PPAR $\gamma 2$ isoform appears to be most abundant in adipocytes (3, 4). In humans, loss-of-function mutations of the PPAR $\gamma$ gene can result in a similar phenotype to that observed in the metabolic syndrome, i.e. insulin resistance/dysglycemia, hypertension and dyslipidemia, all being major risk factors for cardiovascular disease (5). The importance of activation of PPAR $\gamma$ for insulin sensitivity in humans is also demonstrated by synthetic ligands of PPAR $\gamma$, a class of compounds collectively termed thiazolidinediones, that exhibit glucose and blood pressure (BP) lowering properties in subjects with type 2 diabetes $(6,7)$.

In the common Pro12Ala polymorphism of PPAR $\gamma$, which results from a CCA to CGA missense mutation in codon 12 of exon $\mathrm{B}$, the Ala carriers have been reported to exhibit reduced transcriptional activity of PPAR $\gamma$ target genes (8). Although the Ala variant is present in most populations, the allelic frequency varies considerably among different ethnic groups, ranging from 2-23\% (8-10). In several population-based studies, the Ala isoform of Pro12Ala has been associated with relatively lower BMI, improved insulin sensitivity and lower BP (8, 11). However, these findings have been challenged by other trials $(12,13)$. Thus, the 
physiological role of this common PPAR $\gamma$ variant remains unclear and controversial with respect to diabetes, obesity and several components of the metabolic syndrome.

Activation of PPAR $\gamma$ with thiazolidinediones induces increased insulin sensitivity which is accompanied by increased weight. Accordingly, it is possible that the common positive relationship between obesity and markers of cardiovascular disease is affected by PPAR $\gamma$ activation and hence of presence of the Ala polymorphism in diabetes. We recruited 482 patients in the CArdiovascular Risk factors in Patients with DIabetes -a Prospective study in the Primary health care setting (CARDIPP) study in which early markers of organ damage such as increased thickness of carotid intima media, left ventricular hypertrophy by echocardiography and evaluation of pulse-wave velocity were explored. BP were measured with standard office-based method, with 24-hour ambulatory technique and also as a noninvasive recording of central blood pressure. The aim of the study was to explore potential interactions of the Pro12Ala isoform with blood pressure, as a primary objective, but also with markers of the metabolic syndrome, cardiovascular disease and organ damage in middleaged patients with type 2 diabetes, as secondary objectives. Our main hypothesis was that the ALA isoform would be linked with low BP (as in (11)) and we aimed to further explore this by using ambulatory BP in a larger cohort than previously.

\section{Materials and Methods}

\section{Patients}

Patients in the CARDIPP cohort were recruited from 25 primary health care centers in the counties of Östergötland and Jönköping in south-eastern Sweden between the years 2005 and $2008(14,15)$. Men and women aged 55-65 years with type 2 diabetes were enrolled. Patients 
with concomitant severe physical or mental disease such as terminal cancer or dementia were not eligible for inclusion. Specially trained nurses recruited all patients and performed a standardized medical history, anthropometry, and clinic and ambulatory BP measurements. Clinic BP was the average of three seated measurements taken 1 minute apart and ambulatory BP recording was performed with Spacelab 90217 (Spacelabs Inc., Redmond, Washington, USA) as previously described in detail (16). A success rate of at least $60 \%$ of the ambulatory BP recordings was required and fulfilled in 462 subjects. Sagittal abdominal diameter (SAD) was measured with a sliding beam set square as the highest abdominal level above the upper surface of the corresponding bed. Blood samples were drawn following a 10 hour over night fast. Routine laboratory analyses were performed according to the routines at each primary health care center and lipids were analyzed at the Department of Laboratory medicine, Linköping University Hospital, Linköping, Sweden. Levels of apoB and apo AI were measured by immunoturbidimetric assays, Bayer healthcare and Siemens Diagnostic Medical Solutions. Swedish standard Mono-S HPCL was used for HbA1c, giving values approximately $1 \%$ below DCCT-standard (17). Echocardiographic, carotid ultrasonographic and applanation tonometric measurements were performed at the Departments of Physiology at the University Hospital in Linköping and at the County Hospital Ryhov in Jönköping. For the analysis presented in this paper the 36 patients that received treatment with PPAR gamma agonists (rosiglitazone $n=25$, or pioglitazone $n=11$ ) were excluded.

\section{Carotid B-mode ultrasonography of carotid arteries}

The intima-media thickness (IMT) was measured with Philips ATL HDI 5000 (Philips Ultrasound, Seattle, USA) with a 4-7 MHz linear transducer. A longitudinal diastolic image was frozen and a section of $10 \mathrm{~m}$ was examined $1 \mathrm{~cm}$ proximal to the bifurcation of common carotid artery was measured manually by tracing a cursor along the echo wedges. The intra- 
observer variability of IMT in the CCA showed a coefficient of variation of $8 \%$ and the corresponding inter-observer variability was $6 \%$ (18). The mean values of the near and far walls from the right and left sides was calculated and used in the analyses, $n=471$.

\section{Echocardiography}

Echocardiography was performed with the patient in the left semi-lateral position. Briefly, basic measurements according to Penn convention of the diastolic and systolic dimensions of the left ventricle, intra-ventricular septum thickness and posterior wall thickness in diastole were done in M-mode. The Penn convention was then used for the calculation of left ventricular mass, which was corrected for body surface area and expressed as left ventricular mass index (LVMI) (19). Data on LVMI was obtained in 398 patients.

\section{Applanation tonometry}

The radial artery pressure waveform was recorded for 10 seconds with a Millar pressure tonometer and the SphygmoCor system (Model MM3, AtCor Medical, Sydney, Australia). The corresponding ascending aortic pulse wave form was derived from the average radial pulse wave form by using a validated transfer function (20) incorporated in the software (SphygmoCor software, version 7.0) which also provided the calculated central BP, $\mathrm{n}=461$. Aortic and brachial pulse wave transit times were measured with electrocardiogram-gated recordings of the femoral and radial arterial pulse waves, using the carotid arterial pulse wave as the reference site. The surface distances were measured from the supra sternal notch to the carotid, femoral and radial measurement sites, respectively. PWV was calculated by dividing the surface distance with the pulse wave transit time. Successful PWV measurements were obtained in 455 patients. 


\section{Genotyping}

Genomic DNA was extracted from whole blood using Maxwell 16 Blood DNA Purification Kit (Promega, Madison, WI, USA). Genotyping of the PPAR $\gamma 2$ Pro12Ala polymorphism (dbSNP rs1801282) was performed using TaqMan Pre-Designed SNP genotyping assays according to manufactures protocol (Applied Biosystems, Foster City, USA). Allelic discrimination was detected with the ABI prism 7900HT Sequence Detection System using default cycle parameters (Applied Biosystems). Genotyping success rate was $98.9 \%$ and reanalysis of $5 \%$ of the samples was performed in a separate assay showing a genotype concordance of $100 \%$.

\section{Statistical analyses}

PASW 18 (SPSS Inc. Chicago, Illinois, United States) for Windows was used for statistical analyses. Unless otherwise indicated, numerical data are presented as mean values \pm their standard deviations. Between-group analyses were made with independent t-test. All statistical tests were two-sided. $\mathrm{P}$ values $<0.05$ were considered as statistically significant. No formal power analysis was done since an earlier publication by Ostgren et al. of smaller size showed differences in regular office BP between the two isoforms of Pro12Ala of PPAR $\gamma$

\section{Ethics}

The study complied with the declaration of Helsinki and was approved by the Regional Ethical Review Board in Linköping, Sweden. All participants gave written informed consent.

\section{Results}


The total cohort constituted of 482 participants in CARDIPP, not on PPAR $\gamma$ agonists, in which the Pro12Ala isoform of PPAR $\gamma$ was successfully analyzed. Mean age of the participants was $60.7 \pm 3.0$ years and there were 173 women and 309 men. Among women three $(1.7 \%)$ subjects were Ala/Ala, and 36 (20.8\%) were heterozygotes for the Ala variant. Corresponding figures for men were nine (2.9\%) Ala/Ala, and 57 (18.4\%) heterozygotes for the Ala variant. In the total cohort $30.4 \%$ were on diet only, $34.9 \%$ were treated with oral antidiabetic medication $(\mathrm{OAD})$ without insulin and $34.9 \%$ received insulin treatment with or without OAD. Ala homozygotes and heterozygotes were defined as Ala genotype in the analyses.

Results on major anthropometric data, blood lipids and glycemic control are shown in Table 1. Men with Ala isoform exhibited wider waists and higher body weights than homozygotes for the Pro isoform, while no such differences were found in women (Table 1). There were no differences with respect to glycemic control measured as HbA1c in either gender. In women presence of the Ala isoform was related to higher apo A1 levels and a tendency for higher HDL cholesterol levels while lipids were unrelated to the polymorphisms in the men (Table1).

Table 2 shows blood pressure levels and non-invasive measures of cardiac size, intima-media thickness in the carotid arteries, and carotid-femoral PWV in the participants. Male patients with the Ala isoform showed higher diastolic clinic BP and higher systolic 24-hour ambulatory BP levels while the markers of target organ damage, carotid intima-media thickness, left ventricular size, and PWV, were similar in both groups of isoforms. In women, on the other hand, there were no statistically significant differences with regard to BP levels while patients with Ala isoform had lower carotid-radial PWV. 
Of the 482 participants 163 (33.8\%) were without medication for high BP. There were 155 subjects (32.2\%) receiving one anti-hypertensive drug, 103 subjects $(21.4 \%)$ were on two such drugs while $46(9.5 \%)$ and $15(3.1 \%)$ received three or four drugs for high BP, respectively. In men the finding of higher BP, WC and weight was not statistically significant in ALA carriers in the sub-group of patients without anti-hypertensive medication. In women, on the other hand, ALA carriers without anti-hypertensive drugs had higher ApoA1 levels ( $\mathrm{p}=$ 0.031) and lower carotid-radial PWV $(\mathrm{p}=0.026)$ compared with homozygotes of the Pro isoform.

In a model with weight as dependent variable and ALA polymorphism and gender as independent variables, both gender $(\mathrm{p}<0.0001)$ and isoform of ALA $(\mathrm{p}=0.014)$ were related to body weight. Using the same model for analyzing gender-specific interactions of the ALA isoform, differences in carotid-radial PWV $(\mathrm{p}=0,038)$ and systolic night-time BP $(\mathrm{p}=0.026)$ were also gender-specific while the differences in waist circumference, nigh-time diastolic ambulatory BP, left ventricular mass, intima-media thickness and apo A1 levels were not. These gender-specific interactions were unaffected statistically when data of the actual recruiting centre was also added to the models.

\section{Discussion}

We found higher weight and wider waists in men with the Ala isoform of PPAR $\gamma$ compared with homozygotes of the Pro isoform. BMI, on the other hand, only tended to be higher in the same subgroup. Men with the ALA isoform also showed higher systolic BP under ambulatory conditions and higher diastolic BP in the office. However, this was not linked with any differences in LVMI, PWV or intima-media thickness of the carotid arteries. These findings were seemingly unrelated to potential treatment differences of the patients in the two groups 
of Ala isoforms, since the amounts of antihypertensive drugs and use of statins were similar. However, statistical significance was not seen in the small sub-group without antihypertensive medication. The proportions of patients treated with diet only, who were on $\mathrm{OAD}$ or on insulin treatment were also similar in both groups when analyzed with respect to the PPAR $\gamma$ Pro12Ala polymorphism.

The gender differences with regard to risks in relations to the Ala isoform was underlined by the fact that only among women was there a difference with regard to PWV, with the finding of subjects belonging to the Ala isoform displaying lower carotid-radial PWV, i.e. suggestive of a protective rather than, as in males, unfavorable, cardiovascular risk profile in female patients with this genotype. Indeed, women with the Ala isoform also showed higher apo A1 levels, again suggestive of a lower risk for cardiovascular disease.

We found a prevalence of the Ala isoform of the PPAR $\gamma$ Pro12Ala polymorphism in our cohort of patients with type 2 diabetes that was quite high relatively to other populations described earlier (21), but similar (22) or slightly lower (23) than in earlier Scandinavian studies. Gender interactions for the PPAR $\gamma$ Pro12Ala polymorphism have been demonstrated in earlier trials $(24,25)$, but we know of no other survey restricted to type 2 diabetes that incorporated lipid levels in the analyses. In a recent meta-analysis of the Pro12Ala polymorphism, not restricted to diabetes, men in general displayed higher levels of total cholesterol while healthy men had higher levels of HDL-cholesterol (26). This discrepancy with our findings could be due genetic or life-style related factors that are specific for patients with diabetes. 
In an earlier Swedish study of patients with type 2 diabetes a lower office diastolic BP was found among carriers of the Ala gene (11) which was in contrast to the findings in our present study. Indeed, ambulatory blood pressure levels are generally considered to be considerably more reproducible than office $\mathrm{BP}$, and also display a more robust relationship with organ damage, morbidity and mortality (27). Since the present Swedish study was also larger than the study by Ostgren et al from 2003 (11) we believe the data to presented here to be of higher quality.

The small size of our selected population of patients with diabetes is a limitation from a statistical point of view, and this for example makes power in calculations of the ALA isoform as a recessive trait too low. Since we only performed analyses of the Pro12Ala isoform of the PPAR $\gamma$ gene we cannot exclude the possibility that other variants of PPAR $\gamma$, or even related genes, could be affecting our data due to linkage disequilibrium with the Pro12Ala isoform. Such interactions would however not affect the clinical use of determination of the Pro12Ala isoform of the PPAR $\gamma$ gene for prognostic purposes, being used as a gender-specific risk marker.

The Pro12Ala isoform was linked with a reduced risk for diabetes in a recent meta-analysis that covered many different populations, and this was unrelated to the degree of obesity (28). In contrast, we found male ALA-carriers to have higher weight and waist circumference in our cohort of type 2 diabetes, suggestive of increased risk for insulin resistance. A potential explanation for this could be that increased insulin sensitivity in ALA-carriers protects against elevated plasma glucose (28), which would render it necessary to acquire a more pronounced degree of obesity for developing type 2 diabetes in subjects with this genotype, as in our cohort. 
In summary we confirmed the association of the Ala isoform with increased abdominal obesity in men that has been found in some earlier studies (21) while no such relationships were found in women. To our knowledge this is the largest study of the potential impact of the Ala isoform of PPAR $\gamma$ in subjects with type 2 diabetes incorporating three different measurements of BP, office, ambulatory and central BP and we found higher BP in men with the Ala isoform, in contrast to many earlier studies. Interestingly, we found no differences with regard to BP in women, while carriers of the Ala gene displayed lower carotid-radial PWV, i.e. a completely opposite risk pattern compared with males. Furthermore, higher apo A1 levels were found in women with the Ala isoform, underlining a lower cardiovascular risk profile. The interactions between gender and markers of cardiovascular risk in type 2 diabetes with or without the Ala isoform of the PPAR $\gamma$ gene deserve further study.

\section{Acknowledgements}

This study was supported by grants from the Medical Research Council of Southeast Sweden, the Center for Medical Image Science and Visualization (CMIV), the Faculty of Linkoping University, Futurum, GE Healthcare, the Swedish Heart-Lung Foundation, Medical Research council Grant 12661, County Council of Östergötland, and Diabetes Research Centre.

Declaration of competing interests: nothing to declare 


\section{References}

1. Loos RJ, and Bouchard C. Obesity--is it a genetic disorder? J Intern Med. 2003;254:401-425.

2. Evans RM, Barish GD, and Wang YX. PPARs and the complex journey to obesity. Nat Med. 2004;10:355-361.

3. Fajas L, Auboeuf D, Raspe E, Schoonjans K, Lefebvre AM, Saladin R, Najib J, Laville M, Fruchart JC, Deeb S, Vidal-Puig A, Flier J, Briggs MR, Staels B, Vidal H, and Auwerx J. The organization, promoter analysis, and expression of the human PPARgamma gene. J Biol Chem. 1997;272:18779-18789.

4. Chao L, Marcus-Samuels B, Mason MM, Moitra J, Vinson C, Arioglu E, Gavrilova O, and Reitman ML. Adipose tissue is required for the antidiabetic, but not for the hypolipidemic, effect of thiazolidinediones. J Clin Invest. 2000;106:1221-1228.

5. Semple RK, Chatterjee VK, and O'Rahilly S. PPAR gamma and human metabolic disease. J Clin Invest. 2006;116:581-589.

6. Arner P. The adipocyte in insulin resistance: key molecules and the impact of the thiazolidinediones. Trends Endocrinol Metab. 2003;14:137-145.

7. Ogihara T, Rakugi H, Ikegami H, Mikami H, and Masuo K. Enhancement of insulin sensitivity by troglitazone lowers blood pressure in diabetic hypertensives. Am J Hypertens. 1995;8:316-320.

8. Deeb SS, Fajas L, Nemoto M, Pihlajamaki J, Mykkanen L, Kuusisto J, Laakso M, Fujimoto W, and Auwerx J. A Pro12Ala substitution in PPARgamma2 associated with decreased receptor activity, lower body mass index and improved insulin sensitivity. Nat Genet. 1998;20:284-287.

9. Altshuler D, Hirschhorn JN, Klannemark M, Lindgren CM, Vohl MC, Nemesh J, Lane CR, Schaffner SF, Bolk S, Brewer C, Tuomi T, Gaudet D, Hudson TJ, Daly M, 
Groop L, and Lander ES. The common PPARgamma Pro12Ala polymorphism is associated with decreased risk of type 2 diabetes. Nat Genet. 2000;26:76-80.

10. Willer CJ, Bonnycastle LL, Conneely KN, Duren WL, Jackson AU, Scott LJ, Narisu N, Chines PS, Skol A, Stringham HM, Petrie J, Erdos MR, Swift AJ, Enloe ST, Sprau AG, Smith E, Tong M, Doheny KF, Pugh EW, Watanabe RM, Buchanan TA, Valle TT, Bergman RN, Tuomilehto J, Mohlke KL, Collins FS, and Boehnke M. Screening of 134 single nucleotide polymorphisms (SNPs) previously associated with type 2 diabetes replicates association with 12 SNPs in nine genes. Diabetes. 2007;56:256264.

11. Ostgren CJ, Lindblad U, Melander O, Melander A, Groop L, and Rastam L. Peroxisome proliferator-activated receptor-gammaPro12Ala polymorphism and the association with blood pressure in type 2 diabetes: skaraborg hypertension and diabetes project. J Hypertens. 2003;21:1657-1662.

12. Douglas JA, Erdos MR, Watanabe RM, Braun A, Johnston CL, Oeth P, Mohlke KL, Valle TT, Ehnholm C, Buchanan TA, Bergman RN, Collins FS, Boehnke M, and Tuomilehto J. The peroxisome proliferator-activated receptor-gamma2 Pro12A1a variant: association with type 2 diabetes and trait differences. Diabetes. 2001;50:886890.

13. Beamer BA, Yen CJ, Andersen RE, Muller D, Elahi D, Cheskin LJ, Andres R, Roth J, and Shuldiner AR. Association of the Pro12Ala variant in the peroxisome proliferatoractivated receptor-gamma2 gene with obesity in two Caucasian populations. Diabetes. 1998;47:1806-1808.

14. Fredriksson I, Larsson M, Nystrom FH, Lanne T, Ostgren CJ, and Stromberg T. Reduced arterio-venous shunting capacity after local heating and redistribution of 
baseline skin blood flow in type 2 diabetes assessed with velocity-resolved quantitative laser Doppler flowmetry. Diabetes. 2010;

15. Wijkman M, Lanne T, Engvall J, Lindstrom T, Ostgren CJ, and Nystrom FH. Masked nocturnal hypertension--a novel marker of risk in type 2 diabetes. Diabetologia. 2009;52:1258-1264.

16. Nystrom F, Malmqvist K, Lind L, and Kahan T. Nurse-recorded clinic and ambulatory blood pressures correlate equally well with left ventricular mass and carotid intimamedia thickness. J Intern Med. 2005;257:514-522.

17. Hoelzel W, Weykamp C, Jeppsson JO, Miedema K, Barr JR, Goodall I, Hoshino T, John WG, Kobold U, Little R, Mosca A, Mauri P, Paroni R, Susanto F, Takei I, Thienpont L, Umemoto M, and Wiedmeyer HM. IFCC reference system for measurement of hemoglobin A1c in human blood and the national standardization schemes in the United States, Japan, and Sweden: a method-comparison study. Clin Chem. 2004;50:166-174.

18. Dahlen EM, Andreasson T, Cinthio M, Nystrom FH, Ostgren CJ, and Länne T. Is there an underestimation of intima-media thickness based on M-mode ultrasound technique in the abdominal aorta? Clinical Physiology and Functional Imaging. 2011; Epub: Aug 11 DOI: 10.1111/j.1475-097X.2011.01045.x:

19. Devereux RB, and Reichek N. Echocardiographic determination of left ventricular mass in man. Anatomic validation of the method. Circulation. 1977;55:613-618.

20. Pauca AL, O'Rourke MF, and Kon ND. Prospective evaluation of a method for estimating ascending aortic pressure from the radial artery pressure waveform. Hypertension. 2001;38:932-937. 
21. Masud S, and Ye S. Effect of the peroxisome proliferator activated receptor-gamma gene Pro12Ala variant on body mass index: a meta-analysis. J Med Genet. 2003;40:773-780.

22. Rosmond R, Chagnon M, and Bouchard C. The Pro12Ala PPARgamma2 gene missense mutation is associated with obesity and insulin resistance in Swedish middleaged men. Diabetes Metab Res Rev. 2003;19:159-163.

23. Montagnana M, Fava C, Nilsson PM, Engstrom G, Hedblad B, Lippi G, Minuz P, Berglund G, and Melander O. The Pro12Ala polymorphism of the PPARG gene is not associated with the metabolic syndrome in an urban population of middle-aged Swedish individuals. Diabet Med. 2008;25:902-908.

24. Brand-Herrmann SM, Kuznetsova T, Wiechert A, Stolarz K, Tikhonoff V, SchmidtPetersen K, Telgmann R, Casiglia E, Wang JG, Thijs L, Staessen JA, and Brand E. Alcohol intake modulates the genetic association between HDL cholesterol and the PPARgamma2 Pro12Ala polymorphism. J Lipid Res. 2005;46:913-919.

25. Dedoussis GV, Theodoraki EV, Manios Y, Yiannakouris N, Panagiotakos D, Papoutsakis C, Skenderi K, and Zampelas A. The Pro12Ala polymorphism in PPARgamma2 gene affects lipid parameters in Greek primary school children: A case of gene-to-gender interaction. Am J Med Sci. 2007;333:10-15.

26. Huang X, Zhao J, and Zhao T. Effects of peroxisome proliferator activated receptorgamma 2 gene Pro12Ala polymorphism on fasting blood lipids: a meta-analysis. Atherosclerosis. 2011;215:136-144.

27. Boggia J, Li Y, Thijs L, Hansen TW, Kikuya M, Bjorklund-Bodegard K, Richart T, Ohkubo T, Kuznetsova T, Torp-Pedersen C, Lind L, Ibsen H, Imai Y, Wang J, Sandoya E, O'Brien E, and Staessen JA. Prognostic accuracy of day versus night ambulatory blood pressure: a cohort study. Lancet. 2007;370:1219-1229. 
28. Gouda HN, Sagoo GS, Harding AH, Yates J, Sandhu MS, and Higgins JP. The association between the peroxisome proliferator-activated receptor-gamma2 (PPARG2) Pro12Ala gene variant and type 2 diabetes mellitus: a HuGE review and meta-analysis. Am J Epidemiol. 2010;171:645-655. 
Table 1.

Major anthropometric data, duration of diabetes, medication, HbA1c and blood lipids in the 482 participants with type 2 diabetes according to gender and Pro12Ala polymorphism of PPAR $\gamma$. SAD is sagittal abdominal diameter and duration refers to years since the diagnosis of diabetes was established. Ala= heterozygotes and homozygotes of the Pro12Ala isoform of $\operatorname{PPAR} \gamma$.

\begin{tabular}{|c|c|c|c|c|c|}
\hline Variable & $\begin{array}{l}\text { Isoform of } \\
\text { Pro12Ala }\end{array}$ & $\begin{array}{l}\text { Men } \\
\mathrm{N}=309\end{array}$ & $\begin{array}{l}\mathrm{P} \text { value } \\
\text { between } \\
\text { isoforms }\end{array}$ & $\begin{array}{l}\text { Women } \\
\mathrm{N}=173\end{array}$ & $\begin{array}{l}\mathrm{P} \text { value } \\
\text { between } \\
\text { isoforms }\end{array}$ \\
\hline \multirow[t]{2}{*}{ Age (years) } & Pro & $60.8 \pm 2.9$ & \multirow[t]{2}{*}{0.8} & $60.6 \pm 3.1$ & \multirow[t]{2}{*}{0.6} \\
\hline & Ala & $60.8 \pm 2.9$ & & $60.9 \pm 2.6$ & \\
\hline \multirow[t]{2}{*}{ Weight (kg) } & Pro & $91.6 \pm 14$ & \multirow[t]{2}{*}{0.042} & $82.5 \pm 15$ & \multirow[t]{2}{*}{0.17} \\
\hline & Ala & $95.7 \pm 18$ & & $86.5 \pm 17$ & \\
\hline \multirow[t]{2}{*}{ BMI $\left(\mathrm{kg} / \mathrm{m}^{2}\right)$} & Pro & $29.4 \pm 3.9$ & \multirow[t]{2}{*}{0.24} & $30.7 \pm 5.3$ & \multirow[t]{2}{*}{0.13} \\
\hline & Ala & $30.1 \pm 5.1$ & & $32.2 \pm 6.3$ & \\
\hline \multirow[t]{2}{*}{ Waist $(\mathrm{cm})$} & Pro & $104.2 \pm 11$ & \multirow[t]{2}{*}{0.045} & $102.2 \pm 14$ & \multirow[t]{2}{*}{0.8} \\
\hline & Ala & $107.4 \pm 14$ & & $102.8 \pm 14$ & \\
\hline \multirow[t]{2}{*}{$\mathrm{SAD}(\mathrm{cm})$} & Pro & $25.4 \pm 3.4$ & \multirow[t]{2}{*}{0.11} & $24.9 \pm 3.8$ & \multirow[t]{2}{*}{0.5} \\
\hline & Ala & $26.3 \pm 4.6$ & & $25.4 \pm 3.7$ & \\
\hline \multirow[t]{2}{*}{ Duration (years) } & Pro & $7.3 \pm 6.4$ & \multirow[t]{2}{*}{0.8} & $7.7 \pm 5.7$ & \multirow[t]{2}{*}{0.5} \\
\hline & Ala & $7.6 \pm 7.6$ & & $7.0 \pm 6.0$ & \\
\hline \multirow{2}{*}{$\begin{array}{l}\text { Antihypertensive } \\
\text { drugs (no) }\end{array}$} & Pro & $1.17 \pm 1.1$ & \multirow[t]{2}{*}{0.9} & $1.10 \pm 1.0$ & \multirow[t]{2}{*}{0.4} \\
\hline & Ala & $1.15 \pm 1.1$ & & $1.28 \pm 1.1$ & \\
\hline \multirow[t]{2}{*}{ HbA1c (\%) } & Pro & $6.1 \pm 1.2$ & \multirow[t]{2}{*}{0.6} & $6.0 \pm 1.1$ & \multirow[t]{2}{*}{0.6} \\
\hline & Ala & $6.2 \pm 1.1$ & & $6.2 \pm 1.2$ & \\
\hline \multirow{2}{*}{$\begin{array}{l}\text { LDL cholesterol } \\
(\mathrm{mmol} / \mathrm{l})\end{array}$} & Pro & $2.59 \pm 0.71$ & \multirow[t]{2}{*}{0.9} & $2.76 \pm 0.90$ & \multirow[t]{2}{*}{0.9} \\
\hline & Ala & $2.58 \pm 0.73$ & & $2.78 \pm 0.65$ & \\
\hline \multirow{2}{*}{$\begin{array}{l}\text { HDL cholesterol } \\
(\mathrm{mmol} / \mathrm{l})\end{array}$} & Pro & $1.27 \pm 0.34$ & \multirow[t]{2}{*}{0.5} & $1.39 \pm 0.30$ & \multirow[t]{2}{*}{0.059} \\
\hline & Ala & $1.23 \pm 0.28$ & & $1.52 \pm 0.50$ & \\
\hline \multirow{2}{*}{$\begin{array}{l}\text { Triglycerides } \\
(\mathrm{mmol} / \mathrm{l})\end{array}$} & Pro & $1.76 \pm 1.2$ & \multirow[t]{2}{*}{0.4} & $1.74 \pm 0.92$ & 0.8 \\
\hline & Ala & $1.90 \pm 1.0$ & & $1.77 \pm 0.86$ & \\
\hline Apo B (g/l) & Pro & $0.95 \pm 0.17$ & 1 & $0.96 \pm 0.22$ & 0.4 \\
\hline & Ala & $0.95 \pm 0.18$ & & $0.99 \pm 0.18$ & \\
\hline Apo A1 (g/l) & Pro & $1.31 \pm 0.20$ & 1 & $1.35 \pm 0.17$ & 0.030 \\
\hline & Ala & $1.31 \pm 0.20$ & & $1.43 \pm 0.27$ & \\
\hline Apo B/Apo A1 & Pro & $0.74 \pm 0.15$ & 0.9 & $0.73 \pm 0.20$ & 0.9 \\
\hline & Ala & $0.74 \pm 0.15$ & & $0.72 \pm 0.20$ & \\
\hline
\end{tabular}


Table 2.

Levels of office blood pressure (OBP, mean of three seated recordings 1 minute apart), mean 24-hour ambulatory BP (ABP), central BP measured by tonometry (CBP), echocardiographic determination of left ventricular mass index (LVMI), mean carotid intima-media thickness of right and left carotid arteries (IMT), carotid-radial pulse wave velocity (crPWV), and carotidfemoral pulse wave velocity (cfPWV) in patients with type 2 diabetes. Ala= heterozygotes and homozygotes of the Pro12Ala isoform of PPAR $\gamma$.

\begin{tabular}{|c|c|c|c|c|c|}
\hline Variable & $\begin{array}{l}\text { Isoform of } \\
\text { Pro12Ala }\end{array}$ & $\begin{array}{l}\text { Men } \\
\mathrm{N}=309\end{array}$ & $\begin{array}{l}\mathrm{P} \text { value } \\
\text { between } \\
\text { isoforms }\end{array}$ & $\begin{array}{l}\text { Women } \\
\mathrm{N}=173\end{array}$ & $\begin{array}{l}\mathrm{P} \text { value } \\
\text { between } \\
\text { isoforms }\end{array}$ \\
\hline \multirow{2}{*}{$\begin{array}{l}\text { Systolic OBP } \\
(\mathrm{mmHg})\end{array}$} & Pro & $138 \pm 16$ & \multirow[t]{2}{*}{0.24} & $138 \pm 16$ & \multirow[t]{2}{*}{0.7} \\
\hline & Ala & $140 \pm 18$ & & $137 \pm 21$ & \\
\hline \multirow{2}{*}{$\begin{array}{l}\text { Diastolic OBP } \\
(\mathrm{mmHg})\end{array}$} & Pro & $81 \pm 10$ & \multirow[t]{2}{*}{0.03} & $78 \pm 10$ & \multirow[t]{2}{*}{0.6} \\
\hline & Ala & $84 \pm 10$ & & $78 \pm 10$ & \\
\hline \multirow{2}{*}{$\begin{array}{l}\text { Systolic ABP } \\
(\mathrm{mmHg})\end{array}$} & Pro & $130 \pm 14$ & \multirow[t]{2}{*}{0.04} & $129 \pm 14$ & \multirow[t]{2}{*}{0.9} \\
\hline & Ala & $134 \pm 15$ & & $130 \pm 16$ & \\
\hline \multirow{2}{*}{$\begin{array}{l}\text { Diastolic ABP } \\
(\mathrm{mmHg})\end{array}$} & Pro & $78 \pm 8.3$ & \multirow[t]{2}{*}{0.12} & $74 \pm 8.4$ & \multirow[t]{2}{*}{0.8} \\
\hline & Ala & $80 \pm 7.9$ & & $74 \pm 7.9$ & \\
\hline \multirow{2}{*}{$\begin{array}{l}\text { Systolic CBP } \\
(\mathrm{mmHg})\end{array}$} & Pro & $121 \pm 15$ & \multirow[t]{2}{*}{1} & $119 \pm 16$ & \multirow[t]{2}{*}{0.6} \\
\hline & Ala & $121 \pm 14$ & & $121 \pm 19$ & \\
\hline \multirow{2}{*}{$\begin{array}{l}\text { Diastolic CBP } \\
(\mathrm{mmHg})\end{array}$} & Pro & $78 \pm 8.7$ & \multirow[t]{2}{*}{0.6} & $71 \pm 8.5$ & \multirow[t]{2}{*}{0.9} \\
\hline & Ala & $78 \pm 8.7$ & & $71 \pm 9.5$ & \\
\hline \multirow[t]{2}{*}{ LVMI $\left(\mathrm{g} / \mathrm{m}^{2}\right)$} & Pro & $128 \pm 31$ & \multirow[t]{2}{*}{0.6} & $108 \pm 25$ & \multirow[t]{2}{*}{0.4} \\
\hline & Ala & $131 \pm 28$ & & $112 \pm 23$ & \\
\hline \multirow[t]{2}{*}{ IMT (mm) } & Pro & $0.757 \pm 0.21$ & \multirow[t]{2}{*}{0.5} & $0.699 \pm 0.15$ & \multirow[t]{2}{*}{0.4} \\
\hline & Ala & $0.775 \pm 0.19$ & & $0.676 \pm 0.14$ & \\
\hline \multirow[t]{2}{*}{$\mathrm{crPWV}(\mathrm{m} / \mathrm{s})$} & Pro & $9.2 \pm 1.4$ & \multirow[t]{2}{*}{0.4} & $8.5 \pm 1.3$ & \multirow[t]{2}{*}{0.014} \\
\hline & Ala & $9.1 \pm 1.3$ & & $7.9 \pm 1.0$ & \\
\hline \multirow[t]{2}{*}{$\mathrm{cfPWV}(\mathrm{m} / \mathrm{s})$} & Pro & $10.2 \pm 2.2$ & \multirow[t]{2}{*}{0.8} & $10.3 \pm 2.4$ & \multirow[t]{2}{*}{0.7} \\
\hline & Ala & $10.3 \pm 1.6$ & & $10.1 \pm 1.9$ & \\
\hline
\end{tabular}

